\title{
Uterine Corpus Cancer pT1c TNM Finding v6
}

National Cancer Institute

\section{Source}

National Cancer Institute. Uterine Corpus Cancer pT1C TNM Finding v6. NCI Thesaurus. Code C61345.

Uterine corpus cancer with tumor invasion of one-half or more of the myometrium. (from AJCC 6th Ed.) 